Indonesian Journal of Islamic Communication, Vol. 2, No. 2, Desember 2019: 131-142

\title{
KOMUNIKASI JUAL BELI LISENSI PAYTREN DALAM TINJAUAN HUKUM EKONOMI ISLAM (STUDI KASUS DI KANTOR PAYTREN CABANG SURABAYA)
}

Indonesian Journal of Islamic Communication

\author{
Muhammad Hamdi \\ Pascasarjana Institut Agama Islam Negeri Jember
}

Diunggah 01 April / Direvisi 2 Juni / Diterima 6 Desember 2019

\begin{abstract}
Abstrac: The aims of the study are to describe the factual practices of paytren license trading in Surabaya Paytren Headquarter Office and to describe the review of islamic economic law dealing with the factual practices of paytren license trading in Surabaya Paytren Headquarter Office. The study was conducted through field research design by applying qualitative descriptive study. The data were collected through observation, interview and documentation. Triangulation was used to check the validity of the data. The research findings are: 1) The factual practice of paytren license trading in Surabaya Paytren Headquarter Office was done by downloading the application and then opening it, clicking login and register, paying Rp 350.000,-, mentioning ID number to get the license serial number, then entering the number, doing registration, reading the terms and condition, and confirming the data activation through the application, then the application of paytren could be functioned, affiliated with several paytren program and gave an opportunity to earn income by running the bussiness. 2) Based on the islamic economic law, such practice was categorized into Bai' al-Manāfi' 'alā al-Ta'bīd (permanent benefit of trading) which was sahih (valid). It was categorized such way because the object of the transaction was the benefit of the license, not getting goods. The seller was PT. Veritra Sentosa Internasional (Treni) which was represented by Surabaya Paytren Headquarter Office with Wakālah bil 'Ujrah. Dealing with the utterance (șighah) , the partner said "I pay the registration fee Rp 350.000,". Further, the sponsor told him "This is the serial number, please enter it". On the agreement (akad) of Bai' al-Manāfi' 'alā al-Ta'bīd, those utterance had been completed as sīghah, because "This is the serial number, please enter it" meant that I had sold the right of benefit principle of paytren license.
\end{abstract}

Keywords; Komunikasi, trading, paytren license, islamic economic law

Korespondensi: Muhammad Hamdi

Pascasarjana Institut Agama Islam Negeri Jember

h4md1m4ngl1@gmail.com 


\section{A. PENDAHULUAN}

Transaksi bisnis terbagi dua, transaksi sah dan tidak sah. Transaksi sah adalah yang telah memenuhi syarat-syarat dan rukun-rukunnya. Transaksi tidak sah adalah yang tidak terpenuhinya salah satu syarat atau rukunnya. ${ }^{1}$

Terdapat beberapa jual beli yang tidak sah, yakni bai al-ma'dūm (menjual barang tidak ada), bai' ma jūz al-taslìm (menjual barang yang sulit diserahkan), bai' al-gharar (menjual yang terdapat unsur penipuan), bai al-najis wa al-mutanajjis (menjual barang najis dan terkena najis), dan lain-lain. ${ }^{2}$

Berbagai bentuk transaksi jual beli tidak sah tersebut akan menjadi barometer status dari transaksi modern. Berkata Imam Muhyiddīn al-Nawawī :

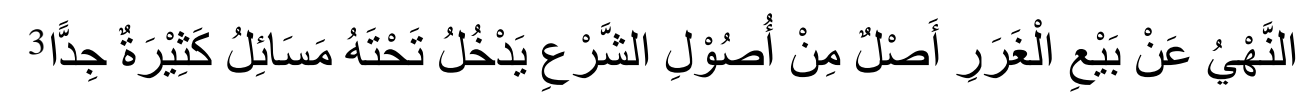

Artinya : "Larangan melaksanakan jual beli gharar adalah salah satu pondasi atau dasar dari sebagian beberapa dasar shara', dimana dibawahnya terakomodir berbagai bentuk masalah yang banyak".

Maka pemahaman aturan jual beli merupakan kewajiban. Tujuannya supaya tidak terjerumus pada transaksi tidak sah" ${ }^{4}$, yang konsekwensinya tidak tercapainya tujuan transaksi, penjual tidak berhak menggunakan uang dari pembeli dan pembeli tidak berhak menggunakan barang yang dia beli, jadi harus saling mengembalikan. ${ }^{5}$

Manusia selalu memerlukan bantuan orang lain. al-Subkī berkata:

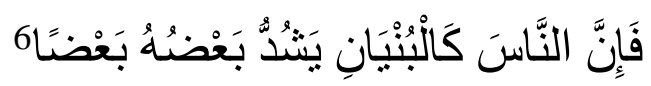

"Maka sesungguhnya manusia itu seperti bangunan, sebagian menguatkan atau menolong sebagian yang lain".

Interaksi sesama diwujudkan dalam mu'āmalah (bisnis). Mu'āmalah yang berasaskan keadilan antara pihak satu dengan lainnya, tidak hanya berlandaskan status sah begitu saja. ${ }^{7}$ Namun zaman sekarang tidak jarang ditawarkan transaksi menggiurkan yang ternyata berdampak pada kerugian, sehingga unsur membantu menjadi hilang. Pada tahun 2012, Mario Halim dan Marselinus Halim membawa sebuah bisnis investasi berbasis Multi Level Marketing (MLM) bernama Talk Fusion.

\footnotetext{
${ }^{1}$ Wahbah al-Zuhailī, al-Fiqh al-Islāmī wa Adillatuhu, vol. 4 (Dimashqī: Dār al-Fikr, 1985), 232-235.

${ }^{2}$ Wahbah al-Zuhailī, al-Fiqh al-Islāmī .... vol. 4, 427.

${ }^{3}$ Wuzāratul 'Awqāf wa al-Shu'ūn al-'Islāmiyyah, al-Mawsū'ah al-Fiqhiyyah, vol. 9 (Kuwait: Dhāt al-Salāsīl, 1983), 186.

${ }^{4}$ Muhammad al-Nawawī al-Jāwī, Mirqātu al-Ṣu ūdi al-Tașdīq fi Sharh Sullami al-Tawfìq ilā Mahabbatillāhi ${ }^{~}$ ala al-Tahqīq (t.tp: Maktabah 'Imāratullāh, t. t.), 50.

${ }^{5}$ Muhyiddīn al-Nawawī, t.t. al-Majmū 'Sharḥ al-Muhadhdhab. vol. 9 (Jeddah: Maktabah al-'Irshād), 192.

6 Taqiyyuddīn 'Ālī bin 'Abd al-Kāfĩ al-Subkī, Fatāwā al-Subkī, vol. 4 (t.tp: t.p, t.t), 362.

7 Abū Ḥāmīd al-Ghazālī, 'Ihyā' 'Ulūm al-Dīn, vol. 2 (Semarang: Toha Putra, t.t), 74.
} 
Ratusan orang mengalami kerugian karena tertipu oleh transaksi baru ini. ${ }^{8}$ Juga Masih hangat ditelinga kita fenomena Dimas Kanjeng Taat Pribadi, menipu banyak orang dengan janji keuntungan dari uang yang disetorkan. Korban merasa ditipu miliaran rupiah karena tak kunjung mendapat hasil penggandaan uang yang dijanjikan. ${ }^{9}$ Fenomena ini memperingatkan kita untuk tidak mudah langsung percaya atas tawaran keuntungan yang dijanjikan setiap orang.

Tahun 2013 lahir produk baru aplikasi bernama PayTren. PayTren merupakan teknologi yang dapat digunakan pada semua jenis telefon seluler atau handphone melalui aplikasi android dan dengan mudah kita dapat melakukan pembayaran melalui ATM/ Internet Banking/ PPOB dan hanya berlaku di lingkungan komunitas intern saja yakni komunitas treni. Paytren menawarkan dua pilihan kategori transaksi, yaitu sebagai pengguna PayTren dan sebagai pebisnis yang turut memasarkan PayTren dan mengembangkan komunitas treni. ${ }^{10}$ Kegunaan PayTren adalah untuk isi pulsa All Operator, pulsa listrik, BPJS, bayar air, bayar cicilan kendaraan, tagihan PLN pasca, TV cabel, beli tiketkereta/peswat, belanja online, șadaqah, 'aqīqah, 'umrah, kurban, tarik tunai di Alfamart dan lain sebagainya. ${ }^{11}$

Pada promosinya, PayTren tidak sekedar menawarkan kemudahan dalam pembayaran. PayTren menawarkan manfaat dan keuntungan lain selain itu, yaitu mendapatkan cashback di semua transaksi, baik transaksi pribadi atau dari transaksi mitra PayTren, sesuatu yang menurut PayTren tidak ada jika bertransaksi di ATM dan loket pembayaran. Cara mendapatkan uang di PayTren ada dua. Pertama uang kecil, yakni didapatkan dari selisih harga jual dan kulakan dalam pelayanan pembayaran listrik, bpjs, telpon, speedy, jual tiket pesawat dan lain sebagainya. Kedua adalah uang besar, yakni dengan ikut menjual lisensi aplikasi PayTren ke banyak orang. ${ }^{12}$

Walaupun populer dan elemen masyarakat meletakkan minat, pro kontra bisnis lisensi Paytren ini tidak bisa dihindari, terutama perdebatan masif di medsos. Maka peneliti memandang penting sekali meneliti status keabsahan jual beli Lisensi Paytren Dalam Tinjauan Hukum Ekonomi Islam.

\footnotetext{
${ }^{8}$ http://www.merdeka.com (September, 2017)

${ }^{9}$ https://nasional.tempo.com (September, 2016)

${ }^{10}$ Tren Indonesia, Edisi VIII 2017, 7.

${ }^{11}$ Tren Indonesia, Edisi VIII 2017, 7.

${ }^{12}$ Tren Indonesia, Edisi VIII 2017, 55.
} 
Penelitian bertempat di Kantor Paytren Cabang Surabaya (Jl. Rungkut Lor, RL $1 \mathrm{C} / 11)$. Pemilihan lokasi ini berdasarkan alasan-alasan berikut :

1. Menjadi pusat pendaftaran Paytren di Surabaya dan kota sekitarnya.

2. Pimpinan kantor ini, yakni Brevmana AP adalah leader Paytren sukses. Dia memperoleh Junior Silver. Junior Silver adalah di atas peringkat Bronze dan Star. Peringkat Star bisa diperoleh dengan mendapatkan mitra 100 di kanan dan 100 dikiri, rewardnya adalah hanphone android atau deposit senilai Rp. 500.000,-Peringkat Bronze bisa diperoleh dengan mendapatkan mitra 500 di kanan dan 500 di kiri, rewardnya adalah lape top atau deposit senilai Rp. 1.500.000,-. Peringkat Junior Silver baru bisa diraih dengan mendapatkan mitra 3500 di kanan dan 3500 di kiri, rewardnya adalah satu sepeda motor atau deposit Rp. 11.250.000,-. Bonusbonus ini belum termasuk komisi-komisi dalam Paytren, seperti komisi sponsor, komisi leadership, komisi generasi sponsor dan komisi generasi leadership. ${ }^{13}$

Maka dalam penelitian ini, peneliti mengangkat judul penelitian Jual Beli Lisensi Paytren Dalam Tinjauan Hukum Ekonomi Islam (Studi Kasus di Kantor Paytren Cabang Surabaya).

\section{B. PEMBAHASAN}

\section{Praktek Jual Beli Lisensi Paytren di Kantor Paytren Cabang Surabaya}

Dalam menjalankan bisnis jual beli lisensi paytren, Kantor Paytren Cabang Surabaya melakukannya dengan promosi dan edukasi. Calon mitra yang memutuskan bergabung dengan paytren, siap dilayani dan dibimbing sampai mahir menggunakan aplikasi paytren dan menjalankan bisnisnya.

Calon mitra yang membeli lisensi paytren di Kantor Paytren Cabang Surabaya didasari oleh beberapa hal. Pertama, ingin mendapatkan kemanfaatan fitur-fitur pembayaran aplikasi. Kedua, ingin mendapatkan peluang usaha berbisnis paytren sehingga berpotensi mendapatkan komisi dan reward. Praktek jual beli lisensi paytren tidaklah rumit. Menurut Brevmana, cukup bermodal android dan uang Rp 350.000,-, sudah bias berubah status menjadi pebisnis paytren. ${ }^{14}$ Menurut Yuli Ainun Najih, unsur-unsur jual beli sudah terpenuhi, baik

\footnotetext{
${ }^{13}$ Brevmana, wawancara, Surabaya, 03 Maret 2018.

${ }^{14}$ Hasil olahan wawancara dengan Brevmana Anugera Pramuliyanto selaku pimpinan Kantor Paytren Cabang Surabaya pada hari Sabtu, 11 Juni 2018
} 
dari sisi penjual, pembeli, șighah dan produk yang dijual. Produknya adalah lisensi paytren yang berupa nomor serial. Dengan memiliki lisensi, maka manfaat aplikasi dan peluang usaha akan didapatkan. ${ }^{15}$

Manfaat peluang usaha paytren maksudnya terjalinnya Wakālah bil 'Ujrah antara perusahaan dengan mitra. Sebagai mitra pebisnis, otomatis menjadi wakil perusahaan dalam memasarkan lisensi. Maka, bila menjalankan bisnisnya, berhak mendapatkan komisi atas pekerjaannya tersebut.

Kunci sukses berbisnis paytren adalah harus bekerja keras yang diimbangi skill memasarkan paytren. Hal ini sebagaimana dituturkan oleh Brevmana, bahwa mitra paytren Surabaya yang sukses adalah yang intens mengikuti seminar dan pelatihan yang diadakan oleh para sponsor dan leader. ${ }^{16}$ Berdasarkan data dari Kantor Paytren Cabang Surabaya, dalam rentang bulan Maret sampai Juli 2018 ada puluhan seminar dan pelatihan paytren yang diadakan dalam rangka meningkatkan skill berbisnis paytren.

Menurut penuturan Brevmana dan Yuli Ainun Najih, tidak ada kekhawatiran perusahaan akan mengalami kegagalan sebab beberapa hal. Pertama, produk perusahaan berupa jasa bayar membayar sangat dibutuhkan terus menerus oleh masyarakat. Kedua, perusahaan telah dilengkapi berbagai perizinan, seperti OJK, APLI, SIUPL, MUI, BI. Sehingga menghindarkan perusahaan dari cekalan pemerintah sebab tidak termasuk perusahaan bodong. Ketiga, perusahaan dan para sponsor tidak menjanjikan sesuatu kepada para mitra, melainkan menawarkan potensi penghasilan apabila menjalankan bisnisnya. Dengan demikian para mitra sudah sadar bahwa mendaftarkan diri di paytren bukanlah menginvestasikan uang yang setelah mendaftar lalu hari-hari berikutnya tinggal menunggu penghasilan tanpa bekerja sedikitpun.

Komisi, cashback dan reward merupakan diantara tujuan seseorang bergabung dengan paytren. Komisi Rp 75.000,- akan didapatkan apabila berhasil mereferalkan paytren kepada mitra baru. Namanya adalah Komisi Penjualan Langsung, konsekwensi akad Wakālah bil 'Ujrah. Menurut peneliti nominal komisi tersebut memang layak dengan kerja keras yang dilakukan. Menurut penuturan

${ }^{15}$ Hasil olahan wawancara dengan Yuli Ainun Najih selaku Leader Kantor Paytren Cabang Surabaya pada hari Sabtu, 11 Juni 2018

${ }^{16}$ Hasil olahan wawancara dengan Brevmana Anugera Pramuliyanto selaku pimpinan Kantor Paytren Cabang Surabaya pada hari Sabtu, 11 Juni 2018 
Yuli Ainun Najih, untuk bisa mereferalkan paytren, dibutuhkan kesemangatan dan skill khusus yang didapat dari pelatihan berbisnis paytren yang mengikutinya rata-rata berbiaya. ${ }^{17}$ Selain skill pemasaran, juga harus berjerih payah terus menerus mempromosikan paytren, online atau offline. Jerih payah tersebut juga akan diganjar komisi Rp 25.000,- apabila mitra berhasil menciptakan group kanan dan kiri, namanya Komisi Pasangan (Leadership). Apabila pebisnis yang direferensikan berhasil mereferensikan juga kepada mitra baru, maka dia mendapatkan Rp 2.000,- sampai 10 generasi dalam timnya, sebab dia ikut andil berjasa membimbing 10 generasi tersebut. Nama komisi ini adalah Komisi Pengembangan Penjualan Langsung. Apabila pebisnis yang direferensikan berhasil mendapatkan komisi leadership, maka dia mendapatkan Rp 1.000,sampai 10 generasi dalam timnya, sebab dia ikut andil berjasa membimbing 10 generasi tersebut. Apabila pebisnis yang direferensikan dan 10 generasi dibawahnya melakukan transaksi bayar membayar, maka dia ikut mendapatkan cashbacknya dari perusahaan. Penghasilan berikutnya adalah promo Ju'alah atau Reward dengan berbagai bentuknya. Promo Ju'alah ini bisa didapatkan apabila dia berhadil mencapai omzet tertentu dari penjualan lisensi paytren.

\section{Praktek Jual Beli Lisensi Paytren di Kantor Paytren Cabang Surabaya Menurut Hukum Ekonomi Islam}

Alasan perusahaan merintis bisnis ini adalah menjembatani kemudahan pembayaran kebutuhan masyarakat dengan menggabungkan kebiasaan menggunakan gadget dan membayar kewajiban. Dengan menggunakan paytren, berbagai pembayaran bisa dilakukan dengan genggaman tanpa keluar rumah, setelah mengisi deposit saldo dalam aplikasi.

Berikutnya perihal transaksi jual beli lisensi paytren yang dilaksanakan di Kantor Paytren Cabang Surabaya, bisa disimpulkan dari pembahasan sebelumnya bahwa transaksi yang dijalankan adalah jual beli lisensi paytren. Jadi ma'qud 'alaihnya berupa lisensi, yaitu nomor serial yang berisi berbagai kemanfaatan.

Pada pembahasan ini, peneliti akan menganalisis hal-hal di atas dari sudut pandang Hukum Ekonomi Islam.

\footnotetext{
${ }^{17}$ Hasil olahan wawancara dengan Yuli Ainun Najih selaku Leader Kantor Paytren Cabang Surabaya pada hari Sabtu, 11 Juni 2018
} 


\section{a. Bentuk Kerjasama Kemitraan Paytren}

Kerjasama kemitraan merupakan bentuk aktifitas tolong menolong antara beberapa orang. Dalam hal ini adalah PT. Veritra Sentosa Internasional (Treni) dengan mitra-mitra bisnisnya, diantaranya adalah Kantor Paytren Cabang Surabaya yang berkomitmen menjaring mitra baru demi menjadi bagian dari perusahaan supaya ikut mendapatkan kemudahan melakukan berbagai transaksi.

Islam telah mengajarkan umatnya untuk meringankan beban orang lain, dalam hal ini diwujudkan oleh PT. Veritra Sentosa Internasional (Treni) dalam menyediakan pelayanan pembayaran. Allah subḥānahu wa ta'ālā berfirman:

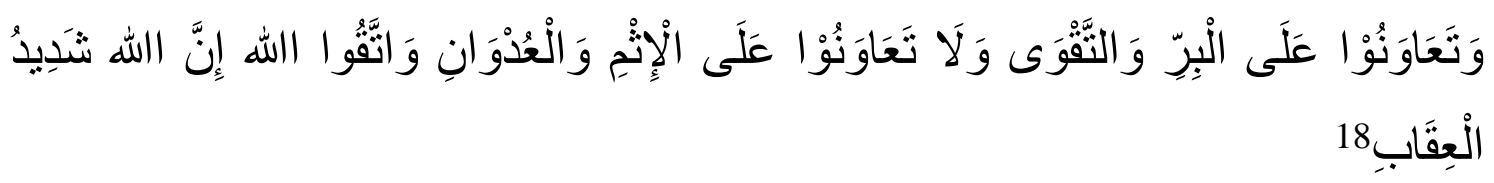

Artinya : "Dan tolong menolonglah kamu dalam (mengerjakan) kebajikan dan takwa, dan jangan tolong menolong dalam berbuat dosa dan permusuhan. Bertakwalah kamu kepada Allah, sungguh, Allah sangat berat siksa-Nya”. ${ }^{19}$

Kerjasama kemitraan dalam bisnis paytren tentunya memberikan manfaat kepada pihak-pihak yang terlibat tersebut.

Adapun manfaat bagi perusahaan antara lain:

(1) Dapat meningkatkan pemasukan. Sebab dengan banyaknya mitra, maka akan banyak pula orang yang akan melakukan transaksi bayar membayar dengan menggunakan aplikasi paytren.

(2) Mendapatkan penghasilan tanpa mengeluarkan tenaga dan biaya banyak, sebab pengguna juga berstatus sebagai distributor.

Adapun manfaat bagi mitra antara lain :

(1) Mendapatkan kemudahan dalam melakukan transaksi bayar membayar, tidak perlu keluar rumah dan mendapatkan cashback transaksi.

(2) Dapat kesempatan berbisnis, baik menjual lisensi atau membuka PPOB.

(3) Bergabung dengan komunitas yang memiliki tujuan positif.

Adapun hikmah dalam kerjasama kemitraan paytren ini adalah adanya tukar menukar manfaat berupa jasa antara kedua belah pihak. Perusahaan

\footnotetext{
${ }^{18}$ al-Qur'ān, 5:2

${ }^{19}$ al-Quran dan Terjemah (Bandung: Penerbit Hilal, t.t), 106.
} 
memberikan jasa bayar membayar berbagai macam tagihan dan mitra berjasa memasarkan aplikasi yang dibuat oleh perusahaan.

\section{b. Jual Beli Lisensi Paytren}

Menurut Hukum Ekonomi Islam, jual beli akan memiliki salah satu status sah atau batal. Jual beli sah adalah yang memenuhi rukun-rukun dan syaratsyaratnya. Jual beli batal adalah yang tidak terpenuhinya rukun-rukun dan syarat-syaratnya. Begitu pula jual beli lisensi paytren yang dipraktekkan di Kantor Paytren Cabang Surabaya. Adapun rukun dari pada jual beli itu ada tiga. Pertama, 'āqidain (penjual dan pembeli). Kedua, ma'qūd 'alaih (barang/manfaat dan alat tukarnya). Ketiga, șighah ('ijāb dan qabūl)

\section{1) 'Āqidain (Penjual dan Pembeli)}

Pada jual beli lisensi paytren ini, berperan sebagai penjualnya adalah perusahaan, sebagaimana Fatwa DSN MUI No. 75 Tahun 2009 tentang Pedoman Penjualan Langsung Berjenjang Syariah (PLBS) bahwa Penjualan Langsung Berjenjang adalah cara penjualan barang atau jasa melalui jaringan pemasaran yang dilakukan oleh perorangan atau badan usaha lainnya secara berturut-turut. Perusahaan adalah badan usaha yang berbentuk badan hukum yang melakukan kegiatan usaha perdagangan barang dan atau produk jasa dengan sistem penjualan langsung yang terdaftar menurut peraturan perundang-undangan yang berlaku. ${ }^{20}$ Lalu perusahaan memposisikan mitra sebagai wakilnya, sehingga juga bisa menjual lisensi perusahaan kepada orang lain.

Lalu Fatwa DSN MUI tentang PLBS nomor 5 dan 12 adalah tentang konsumen dan mitra usaha. Konsumen adalah pihak pemakai barang dan atau jasa, dan tidak untuk diperdagangkan. Mitra usaha/stockiest adalah pengecer/retailer yang menjual/memasarkan produk-produk penjualan langsung. ${ }^{21}$ Disini ada kecocokan antara jual beli lisensi paytren di Kantor Paytren Cab. Surabaya dengan ketentuan umum tersebut. Hal ini karena dalam bisnis paytren konsumen atau pemakai jasa aplikasi bayar membayar tersebut, tidaklah menjual lagi lisensinya sendiri, melainkan lisensi lainnya dari perusahaan.

\footnotetext{
${ }^{20}$ Fatwa DSN MUI No. 75 Tahun 2009 tentang Penjualan Langsung Berjenjang Syariah (PLBS)

${ }^{21}$ Fatwa DSN MUI No. 75 Tahun 2009 tentang Penjualan Langsung Berjenjang Syariah (PLBS)
} 


\section{2) Ma'qūd 'alaih (barang/manfaat dan alat tukarnya)}

Selanjutnya, unsur yang harus terpenuhi adalah ma'qud alaih, yaitu thaman (alat tukar) dan mabī' (barang atau manfaat yang dijual). Seorang pembeli yang telah membayar Rp 350.000,- di Kantor Paytren Cabang Surabaya, mendapatkan lisensi paytren yang merupakan ma'qud 'alaih kategori manfaat. Berikut manfaat lisensi paytren :

(1) Mendapatkan Aplikasi Paytren

Dengan mendapatkan aplikasi paytren, maka mendapatkan manfaat sebagai berikut :

- Bisa melakukan berbagai pembayaran, seperti pulsa hp, listrik, tagihan Telkom, beli voucher game dan lain-lain.

- Bisa menghemat biaya, karena pembayaran dilakukan dalam genggaman, tidak perlu keluar rumah.

- Harga bayar membayar lebih murah dari konter.

- Mendapatkan cashback pada setiap transaksi.

- Bisa menjalankan bisnis berjualan pulsa atau PPOB.

- Setiap transaksi yang dilakukan akan bernilai sedekah.

- Mendapatkan bimbingan dari tim yang solid.

- Deposit 15 ribu dan voucher 225 ribu.

(2) Mendapatkan manfaat program afiliasi, seperti program sedekah, program aqiqoh dan qurban, toko online BelanjaQu, program Fintren, Paytren Academy, terfasilitasi dengan Web Support.

(3) Mendapatkan Peluang Bisnis Penjualan Lisensi Paytren

Peluang bisnisnya berpotensi mendapatkan 6 sumber income paytren, yaitu komisi penjualan langsung, komisi leadership, komisi pengembangan penjualan langsung, komisi pengembangan komunitas, cashback transaksi dan promo ju'alah/hadiah/reward.

Maka disimpulkan, ma'qud 'alaih bisnis paytren ialah manfaat lisensi, berupa nomor serial yang memiliki tiga kemanfaatan di atas yang kepemilikannya permanen. Dalam Hukum Ekonomi Islam, akad terhadap manfaat dinamakan Bai'al-Manāfi ' ala al-Ta'bīd. Uang Rp 350.000,- ditukar 
lisensi paytren yang memiliki manfaat sebagaimana di atas. Maksud dari bermanfaat adalah bermanfaat menurut shar' dan 'urf.

\section{3) Sìghah ('ijāb dan qabūl)}

Berikutnya adalah perihal șighah jual beli lisensi paytren di Kantor Paytren Cabang Surabaya. Langkah pertama pendaftaran adalah mendownload aplikasi paytren, membukanya, meng-klik login, meng-klik daftar/register yang berada di bawah tombol login. Demi dapat lisensi yang berupa nomor serial, harus membayar dulu Rp 350.000,-. Praktek yang terlaksana, sewaktu calon mitra memberikan nominal uang, dia mengucapkan "ini aku bayar biaya pendaftarannya $R p$ 350.000,". Setelah itu sponsor memberikan nomor serial dengan berkata "ini nomor serialnya, silahkan dimasukkan". Dalam perspektif Hukum Ekonomi Islam, dua ungkapan tersebut telah mencukupi untuk dikatakan sebagai șighah. Setelah nomor serial dimasukkan, maka mitra baru sudah bisa masuk dalam aplikasi. Namun sebelum aplikasi bisa aktifasi, mitra baru tersebut harus melakukan registrasi dahulu, membaca ketentuan dan konfirmasi data aktifasi.

Secara khusus, Bai' al-Manāfi' 'alā al-Ta'bīd, yakni akad menjual kemanfaatan secara permanen șighahnya bisa salah satu dari dua șighah. Pertama, ucapan "aku menjual barang ini (semisal tembok) supaya dimanfaatkan meletakkan bangunan baru atau kayu di atasnya". Kedua, ucapan "aku menjual hak kemanfaatan meletakkan bangunan baru atau kayu di atas tembok ini". Adapun ucapan "ini nomor serialnya, silahkan dimasukkan" maksudnya adalah aku menjual hak kemanfaatan aplikasi paytren, dengan demikian telah mencukupi sebagai șighah.

\section{KESIMPULAN}

Berdasarkan penelitian yang telah dilakukan tentang praktek jual beli lisensi paytren di Kantor Paytren Cabang Surabaya, maka didapatkan kesimpulan, pertama; Langkah-langkah pendaftaran paytren di Kantor Paytren Cabang Surabaya adalah mendownload aplikasi paytren, membuka aplikasi, meng-klik login pada pojok kiri atas, meng-klik daftar/register di bawah tombol login, membayar Rp 350.000,-, memberitahukan nomer ID supaya diberi nomor serial, memasukkan nomer serial, 
registrasi, membaca ketentuan, konfirmasi data aktifasi aplikasi, maka aplikasi paytren bisa difungsikan. Kedua; Menurut Hukum Ekonomi Islam, praktek tersebut dikategorikan Bai' al-Manāfi' 'alā al-Ta'bīd (jual beli manfaat secara permanen) yang hukumnya sah. Dikategorikan Bai' al-Manāfi' 'alā al-Ta'bīd karena objek transaksi adalah manfaat dari lisensi, bukan mendapatkan suatu benda. Penjualnya adalah PT. Veritra Sentosa Internasional (Treni) yang diwakilkan kepada Kantor Paytren Cabang Surabaya dengan Wakālah bil 'Ujrah. Perihal șīghah, mitra berucap "ini aku bayar biaya pendaftarannya $R p$ 350.000,". Lalu sponsor berucap “ini nomor serialnya, silahkan dimasukkan". Pada akad Bai' al-Manāfi ' 'alā al-Ta'bīd, ucapan tersebut sudah mencukupi sebagai sighah, sebab maksudnya "ini nomor serialnya, silahkan dimasukkan" adalah aku menjual hak kemanfaatan lisensi paytren.

\section{DAFTAR PUSTAKA}

al-Quran dan Terjemah. t.t. Bandung: Penerbit Hilal.

al-Bujairimī, Sulaimān. 2008. Hāashiyatul Bujairimī 'alā al-Khatīb, vol. 3. Beirut: Dār alKutub al-'Ilmiyyah.

al-Dimyațī, 'Abī Bakr. t.t. 'I'ānatutț̣ālibīn, vol. 3. t.tp. al-Ḥaramain.

DSN MUI, Fatwa No. 75 Tahun 2009 tentang PLBS.

al-Ghazālī, Abu Ḥāmīd. t.t. 'Ihyyā' 'Ulūm al-Dīn. vol. 2. Semarang: Toha Putra.

al-Ḥanbalī, Manșūr al-Buhūtī. 2002. Kasshāful Qina' 'an al-'Iqna'. vol. 7. t.t.p: Wuzāratul 'Adli.

Iskandar. 2009. Metodologi Penelitian Kualitatif. Jakarta: Gaung Persada Press.

al-'Islāmiyyah, Wuzāratul 'Awqāf wa al-Shu'ūn. 1983. al-Mawsū'ah al-Fiqhiyyah. vol. 9. Kuwait: Dhāt al-Salāsīl.

al-Jamal, Sulaimān. t.t. Futūḥātul Wahhāb. vol. 3. Beirut: Dār al-Fikr.

al-Jāwī, Muhammad al-Nawawī. t. t. Mirqātu al-Ṣu 'ūdi al-Tașdīq fi Sharh Sullami alTawfíq ilā Maḥabbatillāhi 'ala al-Tahqīq. t.tp: Maktabah 'Imāratullāh.

al-Mālikī, 'Ibn Rushd al-Qurțūbī. 1982. Bidāyatul Mujtahid wa Nihāyatul Muqtașid. vol. 2. Beirut: Dār al-Ma'rifah.

Moleong, Lexy J. 2014. Metodologi Penelitian Kualitatif. Bandung: PT. Remaja Rosdakarya.

al-Nawawī, Muḥyiddīn. t.t. al-Majmū' Sharḥ al-Muhadhdhab. vol. 9. Jeddah: Maktabah al-'Irshād.

al-Rāfi'î,'Abī al-Qāsim 'Abdul Karīm 'ibn Muhammad 'ibn 'Abdul Karīm. 1997. al-'Azīz Sharh al-Wajīz, vol. 5. Beirut: Dār al-Kutub al-'Ilmiyyah. 
Muhammad Hamdi

al-Shirbinī, Khațīb. 1958. Mughni al-Muhtāj 'ilā Ma'rifati Ma'āni 'Alfāẓil Minhāj. vol. 2. Mesir: Mușțafā al-Bābī.

al-Subkī, Taqiyyuddīn 'Ālī bin 'Abd al-Kāfì. t.t. Fatāwā al-Subkī, vol. 4. t.tp: t.p.

Tren Indonesia. 2017. Edisi VIII.

al-Zuhailī, Wahbah. 1985. al-Fiqh al-Islāmī wa Adillatuhu. vol. 4. Dimashqī: Dār al-Fikr.

http://www.merdeka.com (September, 2017)

https://nasional.tempo.com (September, 2016) 